\title{
PARA ALÉM DE TĒL DĀN: OS CONTEXTOS E CONEXÕES DOS CONFLITOS ENTRE ARAMITAS E ISRAELITAS NA IDADE DO FERRO II
}

\author{
João Batista Ribeiro Santos* \\ Recebido em: 14/06/2019 \\ Aprovado em: 17/08/2019
}

\author{
* Professor da \\ Escola de Teologia, \\ Universidade \\ Metodista de São \\ Paulo.
}

joao.ribeiro@metodista.br

RESUMO: A pesquisa desenvolvida neste artigo situa-se nos processos de expansão dos pequenos reinos levantinos, nos quais as apropriações e desapropriações territoriais ocorreram por meio de guerras estrategicamente ambientadas nas cidades. Lança luz sobre as estruturas de poder palacial no antigo Oriente-Próximo. Desta forma, temos o objetivo de contextualizar historicamente o monumento de Tēl Dān. A descoberta dos dois fragmentos menores, "B1" e "B2", do monumento aramita, que compõem com o fragmento "A" o artefato, completa vinte $\mathrm{e}$ cinco anos. Nossa hipótese é que o artefato extrapola o próprio conflito e seus agentes reais na medida em que o acontecimento tem sua motivação na ausência das guarnições militares do império neoassírio na região após 845 AEC. Com a análise da fonte, buscaremos expor evidências da mapografia política do antigo Israel na primeira metade do século IX AEC e do início da expansão aramita no sul do Levante.

PALAVRAS-CHAVE: Guerra no mundo antigo; antigo OrientePróximo; Aram; antigo Israel; Tel Dan; memória cultural.

\section{BEYOND TELL DĀN: THE CONTEXTS AND CONNECTIONS OF CONFLICTS BETWEEN ARAMITES AND ISRAELITES IN THE IRON AGE II}

\begin{abstract}
The research developed in this paper is located in the processes of expansion of the small Levantine kingdoms, in which the territorial appropriations and expropriations occurred through wars strategically set in the cities. It sheds light on palatial power structures in the ancient Near East. Thus, we aim to historically contextualize the monument of Tēl Dān. The discovery of the two smaller fragments, "B1" and "B2", of the Aramite monument of Tèl Dān, which compose with fragment " $\mathrm{A}$ " the artifact, completes twenty-five years. Our hypothesis is that the artifact extrapolates the conflict itself and its real agents insofar as
\end{abstract}


the event has its motivation in the absence of the military garrisons of the Neo-Assyrian empire in the region after $845 \mathrm{BCE}$. With the analysis of the source, we will try to present evidence of the political mapping of ancient Israel in the first half of the IX century BCE and the beginning of the Aramite expansion in the south of the Levant.

KEYWORDS: War in the ancient world; ancient Near East; Aram; ancient Israel; Tel Dan; cultural memory.

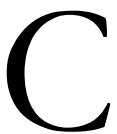

omeçaremos buscando identificar o Estado aramita para, em seguida, analisar a fonte dos acontecimentos - a assim chamada estela de Tēl Dān. ${ }^{1}$ A natureza da sociedade e seu tempo afixam-se nas linguagens da fonte correspondente, em cujo discurso político é descrito o acontecimento - a guerra. As conexões documentárias dos povos levantinos levam-nos a considerar a configuração dos acontecimentos na Idade do Ferro II, perspectivamente tendo como fonte o monumento documental de Tèl Dān quanto ao que diz respeito ao conflito dos dois mais importantes pequenos reinos levantinos e a presença da Assíria (Aššūr), mas também a natureza similar das narrações ou anais locais. Ou seja, as características básicas de documentar os eventos são similares e as desigualdades, identificadas na variação cultural própria de cada região.

Mario Liverani (2010, p. 165) apresenta um postulado altamente importante para a leitura do livro dos Reis da Bíblia hebraica, ${ }^{2}$ ainda não devidamente processado nas pesquisas da história. Para ele, "o conhecimento da tipologia e do desenvolvimento cronológico da antiga escrita da história do Oriente Próximo pode fornecer o quadro geral para uma melhor compreensão do livro dos Reis".

A assimilação de linguagens pelos israelitas teria ocorrido no exílio babilônio (598/597-539), período formativo das identidades - senão ainda étnica, ${ }^{3}$ pelo menos literária e religiosa -, ressalvando especificidades culturais. Precisamente no século IX “as inscrições reais neoassírias em forma analística passam por um notável desenvolvimento em tamanho e detalhe" (Liverani, 2010, p. 169), ao que incluímos as inscrições do rei assírio Shalmaneser

\footnotetext{
1 “Tellé um termo arábico e pode ser rastreado até tilu, a palavra acadiana para montículo. Ele é usado para descrever montes estratificados de depósitos arqueológicos. Tell é sítio que cresce verticalmente como resultado de uma longa continuação de atividades de assentamento e um acúmulo de sedimentos devido a demolição repetida e renivelamento de casas de tijolos de barro" (Knitter et al., 2014, p. 111, n. 30). Consideramos importante anotar que muitos pesquisadores usam o termo "Tel" para inscrições de todas as línguas semitas; mantemos a grafia com exceção para a língua hebraica, para esta grafamos Têl, com o "e" longo de som fechado șerêe/șereêy.

${ }^{2}$ Todas as referências bíblicas citadas ou traduzidas e transliteradas para letras latinas pelo autor têm como fonte a Bíblia hebraica (Elliger; Rudolph, 1997). Com relação aos anos, séculos etc. citados neste artigo, dizem respeito a períodos arqueológicos Antes da Era Comum (AEC), a não ser quando constar informação específica.

${ }^{3}$ Herbert Donner (1997, p. 306-7) supõe que no século IX o desenvolvimento das relações permite "não ser mais possível distinguir etnicamente entre israelitas e cananeus".
} 
III (Šulmānu-ašaridu) e, mais tarde, os reis da dinastia sargônica, período no qual são desenvolvidas as camadas pré-deuteronomísticas por historiógrafos israelitas. Eis uma formalidade exemplar do conteúdo literário, ${ }^{4}$ característica das inscrições reais mesopotâmias proposta como modelo ou influência direta para muitas inscrições reais israelitas: a tomada de poder, a encenação local ou a fuga, a "reforma" do culto (figs. 1 e 2).

Figura 1. Bronze com uma inscrição de Hazael do século IX (Reprodução: Younger, 2016)

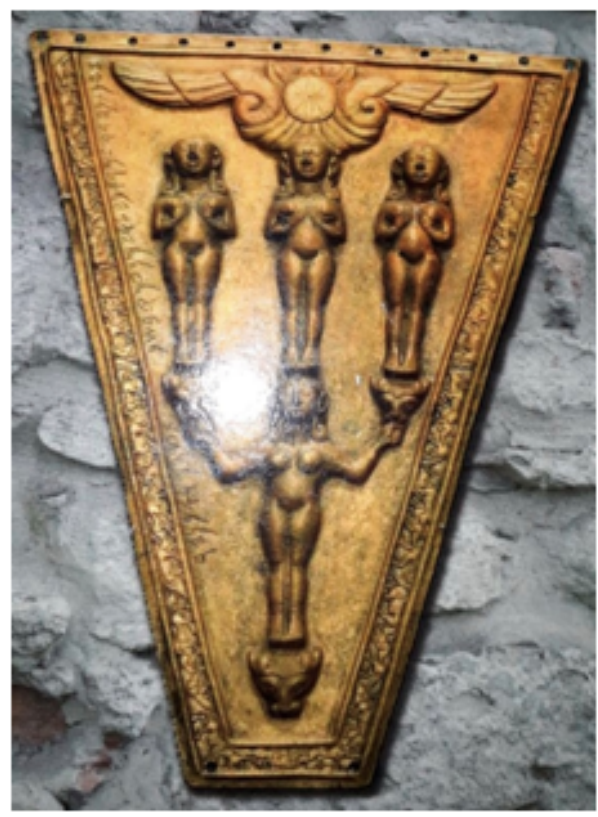

Com efeito, na relação das conexões entre as populações que se mantêm por períodos em lugares previamente estabelecidos por políticas, culturas e meios econômicos, o deslocamento passa a ser um evento no quadro dos modos de vida. Essa mudança na paisagem geográfica sucede as lutas de sobrevivência frente a ameaças comuns, desgaste do meio ambiente local etc.; no entanto, por ser um modo de vida, as antigas transumâncias não fazem parte das ameaças comuns. Constituída como a melhor alternativa para a sobrevivência no verão pelos pastoralistas da planície, esses proprietários sedentarizados nas melhores glebas ou terras partem para os altiplanos em busca de mantimento. Entretanto, nos altiplanos estão assentados os agricultores, pastoralistas e migrantes sem terra nos baixios ou não adaptados à normalização de governos centrais.

\footnotetext{
${ }^{4}$ Para uma aproximação, sugerimos o quadro apresentado por Liverani (2010, p. 179) com as correlações literárias paralelas entre a inscrição de Idrimi (século XV), rei de A-la-la-ḩ, e a narração sobre Joas (Yô’āš, 835-796), rei de Judah (Yəhûdāh).
} 
Figura 2. Inscrição do nome Hazael em vaso do final do século IX (Reprodução: Sass, 2016)

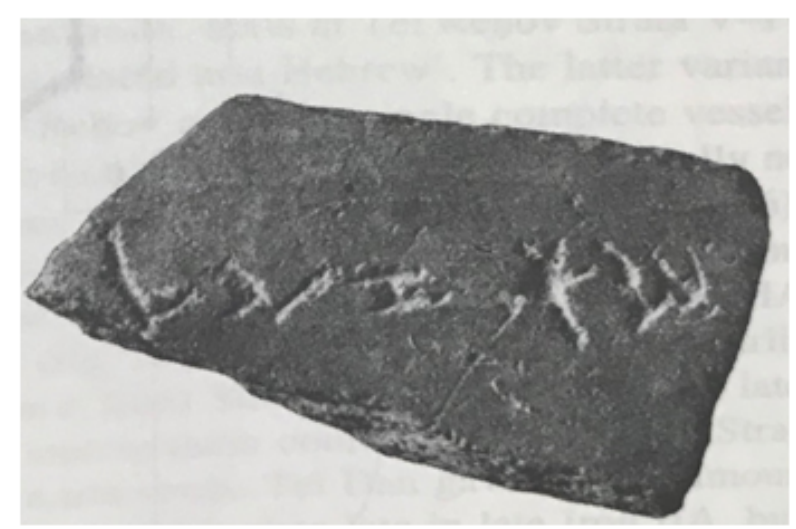

Essa transumância, designada por Fernand Braudel (2016a, p. 147-148; 2016b, p. 137) como "normal", relega o montanhês a arrendatário obrigado a providenciar espaço na montanha para o "proprietário". No inverno ocorre o contrário, a transumância "inversa" na qual os montanheses descem para as planícies por serem menos frias. Além disso, ocorrem os revezamentos circunstanciados pelas condições inelutáveis que vão além do periódico "deslocamento no sentido vertical das pastagens". Apesar de aparentes rupturas, ${ }^{5}$ ao relevo e à estação condicionam-se os cruzamentos culturais no "jogo" das condições físicas, humanas e históricas nos consequentes conflitos.

\section{IDENTIDADE DE ESTADO ARAMITA}

Para pertinências identitárias, os desenvolvimentos de designações étnicas sobre os aramitas, conforme aparecem nas fontes, possibilitam-nos conhecer as composições de política regional dos reis de Aram ('Ārām). A palavra "ārām” apresenta-se em contextos de culturas de mobilidade com representações linguísticas locais. Segundo K. Lawson Younger (2016, p. 35-36), “'̄arām” como linguagem identitária possivelmente ligada aos aramitas ocorre em fontes do terceiro e início do segundo milênio. Younger apresenta numa lista egípcia de nomes de lugares do reino de Amenhotep III (c. 1391-1353) uma figura onde aparece a gravura P3-3rm(w) “aquele de 'Ārām”, na qual Aram está localizada no centro-norte da Síria (Sūriyā), como se fora a terra de A-mur-ru (KUR a-mur-ri; sumério: MART.TU, "amorita”).

Em outra fonte, no Papiro Anastasi III, da época de Merenptah (c. 1213-1203), há uma referência a um oficial da fronteira oriental do Delta do Nilo datada de cerca de 1210, em que o oficial conversa com um colega que chega de uma cidade "no distrito de 'Ārām".

\footnotetext{
${ }^{5}$ Braudel afirma: "o Mediterrâneo, região de cidades, essa verdade banal mil vezes repetida, não é uma novidade, mas é necessário fazer a relação do fato com suas consequências. A ordem humana do Mediterrâneo é a ordem das rotas e a ordem urbana. Ela comanda tudo" (2016a, p. 378). Não o era no primeiro milênio antes da nossa Era?
} 
Tanto um quanto outro documentos são referências para aramitas em documentação egípcia, desde o século XIV. "A lista de Amenhotep parece ser uma referência genuína; no entanto, na minha avaliação, o papiro é incerto", afirma Younger (2016, p. 36). No entanto, as menções de termos com alguma assonância em Ugarit (Ú-ga-ri-it) carecem de confirmação, posto que nas inscrições cuneiformes aludem a nomes de pessoas individuais, não a um território. Em síntese, em documentos de Ugarit, Aram não é atestado como território.

A primeira ocorrência da palavra "ārām" no que se pode atribuir como documentação siro-mesopotâmia consta em inscrições de Tiglat-pileser I (acádio: Tukultī-apil-Ešarra, c. 1114-1076), nas quais é usada a terminologia "Aramita Ahlamû" (ah-la-mì-i KUR ar-ma-ia. MEŠ). Naquelas inscrições, "aramita" aparece como um gentilico étnico no genitivo (ahlamî/ ahlamê armāya) de povos cujas terras estendiam-se no norte do Levante até Anat e Rapiqu a oeste do rio Eufrates (Pu-rat-tu).

Essas populações tribais ficavam mais concentradas nas áreas rurais até a fronteira babilônio-elamita, ao longo das margens do rio Tigre (Idi-ig-la-at) e nos arredores de Uruk e Nippur (Murphy, 2004, p. 78; Younger, 2016, p. 36-7; Bunnens, 2016, p. 254-56; Sergi; Hulster, 2016, p. 5). Nesse caso, Ahlamû representa um registro em leitura tipicamente espacial, ou seja, uma espécie de mapa mental no qual se lê "terra dos aramitas". Com pertinência, Hélène Sader (2010, p. 275-76) acrescenta que Ahlamû é sinonímico de "grupos nomádicos" no período médio assírio; ela faz alusão ao fato de "as inscrições de Tiglat-pileser I (1114-1076 AEC) e Aššur bêl-Kala (1073-1056 AEC) mencionarem Ahlamû kur Armaya, Ahlamû da terra de Aram ou Ahlamû aramitas", referindo-se à região entre os rios Hāābūr e Eufrates.

Em inscrições assírias da Idade do Bronze Tardio, os aramitas aparecem no singular "arumu", genitivo para KUR.a-re-me, enquanto que ahlamû é distintivo para identificação de grandeza socioétnica. Nos contextos neoassírios, tem localização na região ocidental do rio Eufrates entre Balīh e os rios da região do Hāaūr. Durante e depois do reinado de

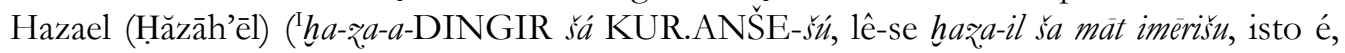
"Hazael da terra de Damasco", c. 844/843-803/802) a cidade-Estado passou a ser referida

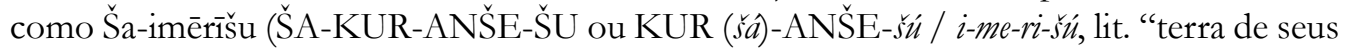
jumentos"). Porquanto,

o termo ahlamû desaparece, exceto em uso arcaico, após o reinado de Adad-nērārī II (c. 911-891 AEC). Mais tarde, a partir de meados do oitavo século, encontra-se a intrigante designação LÚ É $a-{ }^{\ulcorner} \mathrm{ram}$ ' "o povo de Bīt-Aram" em uma carta do arquivo do governador de Nippur. Nas inscrições reais neoassírias e documentação "cotidiana"

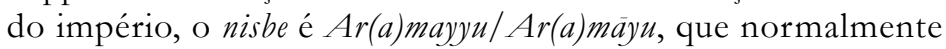
é escrito Ar-ma-a-a, mas raramente Ar-ma-a-ia, fem. Armi/etu (expressões próximas). Nessas fontes a "terra de Aram" pode ser usada, juntamente com "a terra de Hatti”, para designar a área ocidental do rio Eufrates, mas também é usada em textos assírios posteriores para uma localização no sul da Mesopotâmia. As fontes assírias nunca usam "Aram” para designar Damasco. Em vez disso, 
este reino é designado Ša-imērīšu (lit. "de seus jumentos”), Damasco ou Bît-Hazā’ili (“Casa de Hazael”) (Younger, 2016, p. 37).

Por outro lado, nos documentos aramitas e nas fontes assírias "'Ārām" significa exatamente "reino de $\check{S} a$-imèrī̌su", ou seja, os domínios políticos aramitas de Damasco. Assim temos a conexão para as aproximações etimológicas e conflitos políticos com o Israel Norte (Yiśrā’ēl). "A raiz rwm pode significar "exaltado", mapograficamente significa "terra alta"; entretanto, inexiste consenso sobre se "ārām" é um nome geográfico, um nome divino ou um nome pessoal. Younger (2016, p. 38) debate o postulado de Lipiński colocando em dúvida a explanação de fontes aramitas antigas das quais se quer "ārām" como plural de ri'm, "touros selvagens"; sendo "touro selvagem" usado como totem ou uma das numerosas imagens do deus do trovão de Aleppo Haddu. Realmente, parece-nos estranha a associação do grupo socioétnico com grupo de animais de mesma nomenclatura zoológica, constituindo o totem nacional.

Aram compõe a mapografia da região ao norte do Mediterrâneo, sendo Damasco uma importante cidade-Estado daquela região. A reconstrução linguística leva-nos às referências dos aramitas de Ša-imērīšu em narrações da Bíblia hebraica; por exemplo, num local chamado Qîr (קיר). São colocadas em evidência migrações aramitas em paralelo com os êxodos israelitas e migrações de filistitas em Kaptôr. Tais narrações colocam nos contextos a cidade-Estado de Damasco capturada por Tiglat-pileser III (744-727) em 732 e a deportação da sua população para Qîr.

A localização dessa cidade continua incerta, alguns a colocam nas vizinhanças do Elam, enquanto outros a associam com Yebel Bišri. O tablete de İmār/Emar (Tell Mukiš) nomeia o local como ki-ri, proposto por tantos pesquisadores como topônimo de Hurri (Hur-ri, ao invés de ki-ri ou qí-ri) numa leitura do documento de Emar (Īmār) (Younger, 2016, p. 41). Diga-se que Aram-Damasco ('Ārām-Dammeśeq) como nome compósito designando a cidade-Estado, ou reino unido, aparece em narrações da Bíblia hebraica, sempre referida como 'Ārām ou como Dammeśeq. Localizada no sul da Síria, a cidade-estado subsistiu entre 1050 e 732 e "floresceu especialmente entre os séculos nove e oito e foi a maior oponente levantina aos assírios durante esse período" (Younger, 2016, p. 549). Em ambientações hebraicas de conflitos políticos, a entidade era simplesmente 'rm, 'ārām. Na inscrição Panamuwa, narra-se a campanha de Tiglat-pileser III entre 734-732 contra dmšq (Dammeśeq, Damasco ou Ša-imērīšu).

Baseado nisso, Younger (2016, p. 549-53) postula que "tanto Aram-Ṣobah no décimo século (antes de Damasco tornar-se um Estado dominante) quanto Arpad (BītAgūsi) em meados do oitavo século (após Damasco ter declinado em poder) foram referidos durante seus períodos de força simplesmente como 'Aram"'. Portanto, nos seus períodos de

\footnotetext{
${ }^{6}$ Conforme acepção empregada por Ann E. Killebrew (2014, p. 730). A pesquisadora postula que o Israel unificado é uma idealização de escribas e sacerdotes do período após o exílio em Babilônia (Bāb-ilī). No mesmo lugar, Killebrew menciona que Philip R. Davies considera que Israel é uma invenção do final da Idade do Ferro, referindo-se ao reino de Judah.
} 
potência na geopolítica do Levante, territorialmente na Síria, Aram-Damasco era chamado de "'Ārām", com muitas qualificações modificadoras como 'Ārām-bēt Rehob. Mas também, como já enunciado, em documentos neoassírios, entre 853-732, era denominado KUR.

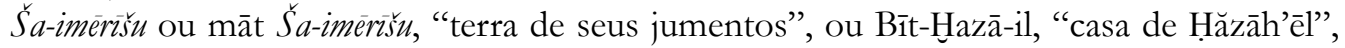
usado particularmente pelos assírios. No reinado de Tiglat-pileser III, os escribas evitavam a ambiguidade do exônimo escrevendo KUR šá-ANŠE.NÍTA.MEŠ-šn-a-a, isto é, "o homem da terra de seus jumentos" - em siríaco Darmsûq. Na sua obra monumental, Braudel (2016a, p. $376,378)$ analisa as rotas mediterrâneas de terra e mar nas quais caravanas rumam a Aleppo (Ha-la-ab), "longas filas de cavalos, de mulas, de camelos", numa instigante comprovação direta da preservação da tradição social. ${ }^{7}$

Figura 3. Estela de Zakkur, rei de Hamāt, agradecendo a Ball-Šemeš pela vitória contra Bar Hadad (Fonte: ART203194 Art Resource, NY)

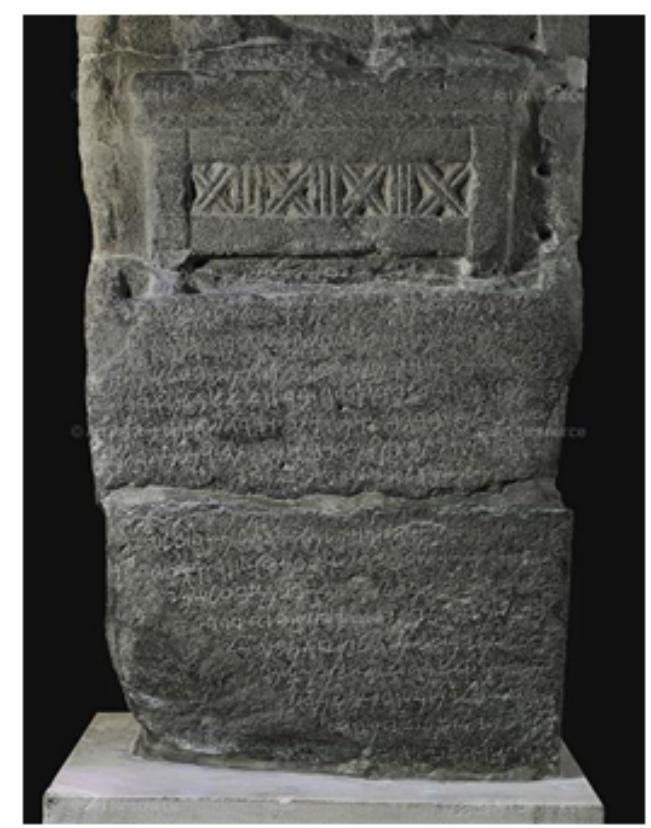

Evidência arqueológica lança luz sobre uma duplicidade identitária dos aramitas de Damasco, numa inscrição monumental "Zakkur, rei de Hamat e Luat, que tem um nome

\footnotetext{
${ }^{7}$ Aqui, como em outros enunciados, a "tradição" tem relação com “costume" porque é perspectivamente conceptual, variável. Para Eric J. Hobsbawm (2018, p. 8-9), “o 'costume', nas sociedades tradicionais, tem a dupla função de motor e volante. Não impede as inovações e pode mudar até certo ponto, embora evidentemente seja tolhido pela exigência de que deve parecer compatível ou idêntico ao precedente. Sua função é dar a qualquer mudança desejada (ou resistência à inovação) a sanção do precedente, continuidade histórica e direitos naturais conforme o expresso na história”.
} 
semita, se não aramita, e que foi considerado no passado como um usurpador aramita de uma dinastia luwiana de Hamat, usou o termo 'Aram' para identificar seu inimigo, o rei de Damasco" (Sergi; Hulster, 2016, p. 5). No monumento de Zakkur (fig. 3), de cerca de 796, lemos: "Bar-Hadad, filho de Hazāili, rei de Aram". O sistema escribal empregado no prefácio desse artefato é assemelhado à inscrição monumental de Tēl Dān no que se refere à sucessão real (Schniedewind, 1996, p. 78), inclusive no típico aspecto teológico: "E Ba‘alšāmayin me fez rei em Hadraš".

\section{Documento de Tél Dān (Tall al-QĀpīi)}

O documento monumental de Tēl Dān consiste em seis importantes estratos: VI-IV correspondem à fase na qual Dān pertencia ao reino aramita de 'Abel Bēt Mā'akāh e depois ao reino aramita de Bēt Rehob (Bēt Ruhūbu) que, segundo Shuichi Hasegawa (2012, p. 73), era um território nas cercanias do vale de Bêt-Šə’ān e localizado cerca de seis quilômetros a oeste do rio Jordão. Para Hadi Ghantous (2013, p. 37), essa fase encerra-se com a conquista da cidade de Dān por Omri ('Omrî) na primeira metade do século IX e com a reconquista de Hazael (fig. 4) no início da segunda metade do mesmo século. O estrato III representa o período da ocupação de Dān por Hazael, agregando grande área citadina durante a segunda metade do século IX. Em relação ao estrato II, a referência histórica é a ocupação israelita da cidade após a conquista de Joas (Yô’āš) e Jeroboam II (Yārābə‘ām II, c. 787-747 [c. 782 753]), relativamente após 732 .

Os três fragmentos do documento monumental foram encontrados no estrato II, do período da ocupação israelita de Dān, conquistada por Jeroboam II. Desta ocupação, seguramente a inscrição foi realizada antes da conquista, com sua forma de inscrição assemelhada, segundo Ghantous (2013, p. 39, 43), com outras inscrições do noroeste semítico do mesmo período. ${ }^{8}$ Além disso, a inscrição teria sido redigida no estrato Dān III e reutilizada fragmentariamente durante Dān II. Sigurður Hafpórsson (2006b, p. 223) resume o quadro arqueológico: o sítio mede 18 hectares de largura, quase retangular, com suas extremidades medindo 18 metros acima da planície do seu entorno; "um complexo cúltico, um recinto medindo cerca de 60 × 45 metros de pedras de cantaria, pithoi com decorações de cobra, um lugar para incenso, entre outras coisas, foram escavados no estrato IV. Uma coleção de

\footnotetext{
${ }^{8}$ Sobre os semitas: "Sea cual fuere la historia más antigua de esas gentes, fuera de nuestro alcance, pero que parece haber girado alrededor de Arabia antes de su desertización, todo nos lleva a pensar que, a partir del cuarto milenio como muy tarde, una notable concentración de población se reunía en el territorio hoy sirio, en las franjas septentrionales del gran desierto sirio-árabe, o más bien de ganaderos con ganado menor, que vivían como seminómadas en función de los pastos. Más tarde, en plena época histórica, desde finales del tercer milenio, podemos imaginar a pequeños grupos, tentados por la existencia menos tosca y más gratificante de los mesopotamios, uniéndose a éstos tras seguir, en grupos más o menos grandes, el curso del Éufrates, para hacerse finalmente sedentarios entre ellos, más o menos vencidos y absorbidos, antes o después, por esta opulenta civilización" (Bottéro, 2001, p. 29-30).
} 
cerâmica fenícia foi encontrada em um depósito ao norte do local de culto". Como nota, o estrato IV A-B tem periodização entre os séculos XI-X. Nesse mesmo Dān citado na Bíblia hebraica, o assentamento israelita ocorreu na Idade do Ferro I.

O documento monumental ou estela de Tēl Dān consiste em três fragmentos de antigas letras aramitas inscritas com um cinzel na superfície de uma pedra plana de basalto; todos os fragmentos foram encontrados no lado sul do sítio. "Os estudiosos concluíram que Hazael, rei de Aram-Damasco compôs o texto na estela na segunda metade do século IX AEC, no qual descreveu o assassinato de dois reis, Joram de Israel e Ahaziah de Judah" (Hasegawa, 2012, p. 35). No artefato há uma reconstrução histórica dos conflitos entre Aram-Damasco e Israel à época. Uma das causas da dificuldade para a datação da fonte consiste na inexistência do nome de seu autor, restando para análise a perspectiva contextual.

Figura 4. Hazael de Damasco

(Fonte: ART49197 Art Resource, NY)

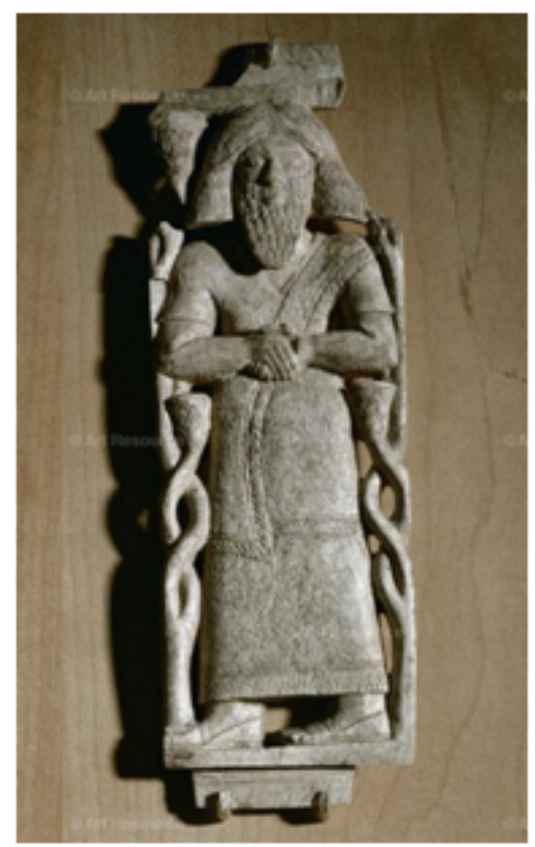

Avraham Biran e Joseph Naveh (1993, p. 85; 1995, p. 2) afirmam que o assim chamado "Fragmento A", descoberto em 1993 E.C., estava no nível de base de um largo pavimento no canto sudeste da praça da cidade e deve ter sido usado antes da invasão da Assíria. Evidências arqueológicas recolhidas do complexo de portões, das câmaras e pavimento, atestam a destruição do local em 733/732, época da conquista do norte levantino por Tiglatpileser III. Assim, a utilização do artefato como material de construção pode ser datada dessa

\footnotetext{
${ }^{9}$ Relevo de rocha ígnea eruptiva.
} 
mesma época. Hafpórsson (2006a, p. 51-52) e George Athas (2006, p. 248, 253) entendem que o artefato foi erigido antes do ano 800, talvez 796. O assim chamado "Fragmento B1" foi encontrado em 20 de junho de 1994 da nossa Era, um artefato medindo cerca de 20 centímetros de altura e 1.4 centímetro de largura com seis linhas de inscrições num espaço de 15 x 11 centímetros. Esse fragmento estava numa área de fortificações israelitas em que existia a construção de uma bāmāh no topo do nível das destruições operadas pela invasão assíria no Israel Norte entre 733/732 (Biran; Naveh, 1995, p. 1-2). "Nos detritos a 0,80 metro acima do nível do pavimento. O detrito é atribuído à campanha militar de Tiglat-pileser III ao norte de Israel” (Hasegawa, 2012, p. 36); assim, “o Fragmento B1 foi encontrado cerca de 13 metros ao sudoeste do Fragmento A" (Ghantous, 2013, p. 37).

Dez dias depois da escavação do "Fragmento B1" encontrou-se o assim chamado "Fragmento B2", distante 40 metros do portão, tendo cinco mașseēbôt ao fundo, artefato que teria sido reutilizado como pavimento. Notável é o fato de que essa pavimentação é do final do século IX e início do VIII, mas o documento é contemporâneo do "Fragmento B1". "Infelizmente, as letras do Fragmento B não constituem uma continuação direta do texto do Fragmento A em qualquer linha, e nenhuma linha no Fragmento B está completa em seu final. No entanto, na maioria das linhas, após a restauração de algumas letras entre os fragmentos e nas extremidades da linha, um texto mais ou menos significativo foi obtido" (Biran; Naveh, 1995, p. 11). Ainda que a reconstrução linguística, realizada primeiramente por Joseph Naveh, seja confiável, o debate em torno do monumento justifica aqui a presença de outros pesquisadores.

Quase que consensualmente (Millard, 2000; Hasegawa, 2012; Ghantous, 2013; cf. Galil, 2001, p. 16-21), os relatórios arqueológicos concluem que os três fragmentos são do mesmo estrato e sua reutilização como material de construção deu-se tempo depois, nas reconstruções do período da guerra com o império neoassírio. Destarte, Ghantous (2013) entende que a relação entre os fragmentos ainda carece de melhor comprovação. Por outras palavras, as possibilidades de encaixe dos fragmentos suscitam controvérsias. Há quem, baseando-se no alinhamento de letras do "Fragmento A", inclinadas para baixo, enquanto as letras do "Fragmento B" são mais lineares, menores e em formato inteligível, suponha que "as locações de cada fragmento decidiram as formas, os tamanhos e os espaços entre as letras" (Hasegawa, 2012, p. 37). Nesse caso, o posicionamento do escriba, fixando-se na margem inferior da inscrição ao escrever na pedra e necessitando esticar o braço para escrever as partes superiores do texto, resultou nas mudanças de marcas e na irregularidade de linhas. No entanto, não podemos deixar de observar os diferentes tamanhos dos artefatos, por influir diretamente no formato da escrituração.

Conjetura-se que tenha havido dois trabalhadores, um escriba e um artesão de gravuras, não tendo o artefato passado por correção mesmo com o posicionamento aparentemente desconfortável do escriba para escrever a parte superior. Por outro lado, o documento deve ter sido construído em fragmentos, sendo eles conectados durante ou após a exibição pública. Essa é uma argumentação razoável para o desalinhamento apresentado pela 
fonte..$^{10}$ No entanto, a dessemelhança formal não exclui a possibilidade de os três fragmentos formarem uma mesma inscrição. ${ }^{11}$ Erhard Blum (2016, p. 37-38) posiciona-se contrário ao argumento de que é diferente a direção das linhas nos fragmentos $\mathrm{A}$ e B, afirmando que podemos ler os fragmentos combinados cruzando as fraturas sobre sete instâncias: "linhas $3 / 4$ [B-A]; 4 [A-B]; 4-5 [B-A]; 5 [A-B]; 5-6 [B-A]; 6-7 [B-A]; 7-8 [B-A]; 8 [A-B]; 8-9 $[\mathrm{B}-\mathrm{A}]$ ". Como reconhecido por Blum, a combinação proposta é pura coincidência.

Um dado, porém, suscita dúvida quanto à quantidade de escribas e artesãos. Apenas como suposição, Ghantous (2013, p. 44) lembra que Peter Niels Lemche afirmou que "o fato de os elementos-chave, as palavras 'Rei de Israel' e 'Casa de David', serem encontrados nas linhas 8-9, bem no centro do Fragmento A, promove a suspeita de que um falsificador os teria colocado propositadamente". O nome dos escribas (e artesãos) que elaboraram o documento de Tēl Dān ou não foi registrado ou não resistiu aos manuseios e à utilização a que o documento foi submetido.

Diversos pesquisadores têm identificado o autor com Hazael de Damasco, considerando a menção de dois reis e suas mortes: o rei de Israel, cujo nome termina com "-ram" ( ᄀ), e o rei de Judah (Yəhûdāh), da Bêt Dawîd, cujo nome termina com "-iahu” (why). Com a atestação da cronologia histórica, os reis seriam respectivamente Jehoram (Yəhôrām, 852/51-841 [848-842]) de Israel e Ahazyahu ('Ăhazəyāhû,-842) de Judah. Mas não apenas isso: não obstante outras instâncias de análise, vários relatórios do contexto arqueológico e a paleografia do documento têm levado a identificar o autor com Hazael (Finkelstein, 2007, p. 149; Kottsieper, 2007, p. 119; Hasegawa, 2012, p. 42-43; Younger, 2016, p. 592).

Inicialmente, Biran e Naveh (1993) entendiam que o autor do artefato teria sido um rei vassalo de Aram-Damasco, Bēt Rehob ou 'Abel Bēt Mā'akāh, e seu senhor era Adad-'idrī. Com a descoberta dos fragmentos B1 e B2, esses dois descobridores, em novo relatório analítico (Biran; Naveh, 1995; cf. Schniedewind, 1996, p. 85), passaram a atribuir a autoria a Hazael, mas sugerindo tais fragmentos como partes de um conjunto. Gershon Galil (2001, p. 16-17) e Athas (2006, p. 249) atribuem o documento monumental a Bar-Hadad II, filho e sucessor de Hazael, ${ }^{12}$ e Hafpórsson (2006a, p. 64) afirma que Hazael e Bar Hadad II são os possíveis autores, reconhecendo, no entanto, os muitos problemas de identificação. No resultado de suas pesquisas, Galil e Athas consideram extremamente difícil a junção dos fragmentos como um conjunto lógico.

\footnotetext{
${ }^{10}$ Shuichi Hasegawa (2012, p. 37-38) mapeia o artefato com o auxílio das conclusões de vários pesquisadores.

${ }^{11}$ Para Ghantous (2013, p. 39), talvez a variação no roteiro e na forma indique uma recentemente adquirida capacidade literária.

${ }^{12}$ Ghantous $(2013$, p. 45, 47) argumenta considerando a ampla reconstrução do contexto histórico: “A atribuição da inscrição a Hazael ganha mais apoio a partir da insistência de que o deus Hadad tenha feito o autor da inscrição rei (B4 "YHMLK HDD”). Porque ambos os registros assírios e bíblicos apresentam Hazael como um usurpador no trono de Damasco, é mais provável que Hazael esteja por trás da escrita da inscrição de Dan do que Bar-Hadad”.
} 
Com análise linguística baseada nas apresentações de Biran e do também linguista Naveh, Ingo Kottsieper (2007, p. 106-107) decide sem ressalvas desqualificar a pesquisa de Athas ao afirmar que "a reconstrução proposta por Athas, que argumenta com as diferentes inclinações das linhas - ignorando o fato de que elas estão se curvando - é baseada nas mais improváveis especulações" ${ }^{13}$ Antes, porém, neste mesmo campo de abordagem, Galil justificou a sua atribuição de autoria a Bar Hadad II destacando o fato de Hazael ter sido um usurpador, a menção ao pai e a aparentemente mencionada morte de Hazael no Fragmento A, linha 3. Além disso, os fragmentos B1 e B2 devem ser colocados antes do Fragmento A, desenhando uma nova configuração do artefato baseada em que

a parte principal da inscrição trata do período de Bar-Hadad, filho de Hazael. As palavras que têm sido preservadas não permitem uma reconstrução razoável dos eventos. É obviamente uma "inscrição sumária”. O rei de Aram se orgulhava de suas vitórias sobre muitos reis e seus grandes exércitos ([r]kb.w’lpy prs $)$. A menção do rei de Israel e do rei de Judah (byt dwd) e "suas terras" ([']t.'rk.hm) talvez indique a subjugação de Israel e Judah a Aram, que é mencionada na Bíblia (2Reis 12.19ss; 13.7) (Galil, 2001, p. 18).

Ora, a aceitação desse novo encaixe das peças traz consigo como razoável a menção nas últimas linhas da inscrição monumental à coroação de Joas como rei em Israel, em cerca de 805. Nesse caso, a revolta israelita teria ocorrido como reação às anexações aramitas de terras a oeste do Jordão, inclusive Dān, na época do rei assírio Adad-nērārī III (810-783), que as "Crônicas Epônimas” datam em 805-803 e 796, sendo uma expedição em 802 (Galil, 2001; Younger, 2016). Mesmo a reconstrução das linhas 5-10, destacando a menção à Bêt Dawid nas linhas 7-9, na avaliação de Nadav Na'aman (2000, p. 99) não passa de especulação. A nosso ver, o debate reside nas textualizações do documento de Tēl Dān e da Bíblia hebraica. Tais fontes, no que se referem aos mencionados reis, mantêm-se conflituosas.

$\mathrm{Na}$ Bíblia hebraica, ${ }^{14}$ Jehu é retratado como assassino de Yehoram e Ahazyahu, diferente do artefato aramita, que exalta a Hazael por tal ato. Permanece, portanto, a dificuldade de completa elucidação. Avraham Biran e Joseph Naveh (1993; 1995), os primeiros editores do documento, têm sugerido Jehu como agente de Hazael para assassinar os dois reis, comparando o verbo ljq do documento com o verbo acádio dâku em documentos reais assírios - além de explanar a forma como "atacar, derrotar", ao invés de "matar". Shigeo Yamada $(1995$, p. 614, 619) talvez seja um raro pesquisador a notar a superioridade militar israelita sobre Aram no documento monumental de Tēl Dān. Ele questiona o fato de Hazael ter matado os reis Yehoram e Ahazyahu em Rāmōt Gilə‘ād (Tell er-Ramit), na Transjordânia Setentrional, pelo exagero da fonte e pela informação da morte de dois reis numa mesma

\footnotetext{
${ }^{13}$ Apesar de ter publicado sua pesquisa em 2007, Kottsieper toma como alvo para os seus postulados uma antiga pesquisa de Athas (2003), não a mais recente na qual ele revisa os mais importantes pontos da sua interpretação do documento monumental de Tèl Dān (2006).

${ }^{14}$ Cf. 2Reis 9.24, 27 (Elliger; Rudolph, 1997).
} 
batalha, como se ambos estivessem desprotegidos. Além disso, qụl (acádio: dâku), comumente traduzido por "morte", é melhor entendido por "derrota". Nesse caso, Hazael teria então derrotado os reis do sul do Levante. Na sequência, Jehu toma o poder. Sobre estes e outros postulados, Shuichi Hasegawa (2012, p. 44) analisa:

É inconcebível que Hazael, em sua inscrição, descrevesse um evento em que ele não tenha participado. As consequências do golpe de Jehu também não se encaixam na aliança hipotética entre Hazael e Jehu. No ano 841 AEC, Hazael lutou contra a Assíria, e apesar da grande devastação causada em sua terra, ele não se submeteu. Jehu, por outro lado, submeteu e pagou impostos à Assíria no mesmo ano. Assim, Damasco e Israel tiveram diferentes atitudes em relação à Assíria, e isso contradiz a suposição de que Hazael e Jehu eram aliados. Que a rivalidade prevaleceu entre os dois reinos é confirmado pela invasão de Hazael e pela conquista de uma grande parte do território israelita.

De fato, a derrota do rei israelita para Hazael na guerra de Rāmōt Giləād e o assassinato dos reis por Jehu, mesmo que seja tomado o longo relato da Bíblia hebraica como referência, são insuficientes para afirmar que a sequência dos fatos pressupõe um pacto ou agenciamento entre aqueles dois líderes militares, como propõe William M. Schniedewind (1996, p. 84-85), mas também como sugerem Biran e Naveh (1993; 1995). As condições políticas são desfavoráveis pela individualização quanto às proteções de fronteiras, diferentes do projeto de barrar os avanços do inimigo comum, a saber, o rei Shalmaneser III, nos conflitos de 853 e, com a coalizão dos doze reis levantinos, em 849, 848 e 845.

Busca-se, então, as identidades das fontes documentárias, tais como a época e o gênero. É inconsensual que a elaboração do documento tenha ocorrido durante o reinado de Hazael. Quanto à narração hebraica sobre Jehu, é razoável datá-la durante o reinado dele, com tradição oral de longa duração e posteriormente escriturada na época em que Dān era controlada por Aram-Damasco. Nessa época, o poder de Hazael estendia-se em grande parte do sul do Levante, "ou durante a primeira parte do reinado do seu filho Bar-Hadad II" (Ghantous, 2013, p. 45), que foi abandonando gradualmente os territórios além da Síria. As verificáveis mudanças ocorridas na tradição oral foram incorporadas à edição documental.

A longa duração das tradições orais, o uso de lendas nos ciclos proféticos e o conflito com fontes coetâneas levam-nos a priorizar o documento de Tēl Dān por ser uma fonte dentro da margem temporal dos testemunhos. Nesta mesma linha de raciocínio, indicamos que a atribuição a Jehu pela morte dos reis está sugerida por tradições proféticas de oposição à Bêt 'Omrî. Isso fortalece o entendimento de que tenha sido Hazael o responsável pela morte dos reis em Rāmōt Giləād - até a informação de que wayyakkêu 'ărammîm 'et-Yôrām a isso corrobora ${ }^{15}-$, permanecendo a possibilidade de Jehu ter exterminado a linhagem de parentesco de Ahab. Problemas com as retroprojeções ficam fortemente acentuados nas

15 "E feriram os aramitas a Yôrām" (2Reis 8.28; cf. Elliger; Rudolph, 1997). 
memórias de locais mapográficos, acerca das quais ainda explanaremos. Há contradições históricas na narração da guerra de Yehoram e Ahazyahu contra os aramitas. Nesse sentido,

a primeira contradição é entre 2Reis 8.28 , onde Ramot-Gilead parece estar nas mãos dos aramitas e os israelitas na ofensiva, e 2Reis 9.14b, onde os israelitas parecem defender Ramot-Gilead contra o ataque de Hazael. Uma segunda contradição gira em torno de se Ahazias foi com Joram para lutar contra os aramitas em Ramot-Gilead (2Reis 8.28a) ou se Joram foi sozinho para lutar contra Hazael em Ramah e Ahazias visitou Joram ferido em Jezreel (2Reis 8.29b). Ramah é omitida em 2Reis 9.15a, o que de outra forma é idêntico a 2Reis 8.29a, como se alguém tentasse resolver a segunda contradição. A última contradição diz respeito à direção da fuga de Ahazias em 2Reis 9.27. Isto é identificado, ao mesmo tempo, como a estrada de Bet-Haggan, onde ele foi morto na subida de Gur perto de Ibleam, e como o caminho de Ibleam para Meggido (Ghantous, 2013, p. 144).

Estes e outros problemas implicam colocar forçosamente a textualização do documento hebraico como fonte metodologicamente comparativa. Aqui sobressai uma inquirição: qual a intenção de se querer Jehu como assassino dos reis de Israel e Judah? A carga profética contra a Bêt 'Aḥ'āb seria necessariamente a resposta. Mas denúncias estão em torno de lendas e nada se diz sobre o grande desenvolvimento político-econômico desde Omri, mas das relações internacionais, testemunhadas por fontes materiais aramitas e assírias. Destaquemos a economia palatina:

A menção a milhares de bigas no relato da batalha de Carcar, em 853 a.C., fornece bom testemunho para este desenvolvimento [produção de cobre em Khirbet en-Nahas]. Khirbet en-Nahas deve ter fornecido muito desse cobre; relações comerciais com o Chipre - a mais importante fonte de cobre do leste do Mediterrâneo tinham quase cessado no final do século XII e foram aparentemente retomadas somente na segunda metade do século IX a.C. O cobre de Khirbet en-Nahas deve ter fluído para o norte, ao longo da Estrada dos Reis, na Transjordânia, e para o Egito e a planície costeira. A Estrada dos Reis foi dominada pelas fortalezas omridas, em Moab e em Galaad, e a planície costeira foi governada por Gezer e pelo porto de Dor. Isso significa que Israel deve ter sido o beneficiário mais significativo da indústria de cobre e do comércio no Levante (Finkelstein, 2015, p. 140-41).

Não obstante esses fluxos de produção, os mecanismos de apropriação estatais motivaram a rápida adesão de parte da sociedade ao golpe. "Fortes tensões sociais marcam vistosamente um período que os dados arqueológicos mostram ter sido de grande desenvolvimento econômico e de assentamentos", postula Liverani (2008, p. 167) acerca do reino de Jeroboam II, mas cuja abertura do processo tem início no reinado de Omri. Assim, 
a informação histórica derivada das inscrições de Tel Dan traz à tona a relação entre as mortes de Joram e Ahaziah e a ascensão de Jehu ao poder. Depois que o exército de Hazael matou Joram e Ahaziah em Ramoth-Gilead, Jehu perpetrou um golpe de Estado e matou o resto da casa de Ahab em Jezreel (Hasegawa, 2012, p. 46).

Os conflitos militares entre israelitas e assírios durante o reinado de Ahab e sua expansão para além das fronteiras do vale do Jordão podem estar na origem da queda da casa real.

\section{A natureza do documento de Têl Dān (Tall al-QĀọī)}

Translação do Fragmento $A$

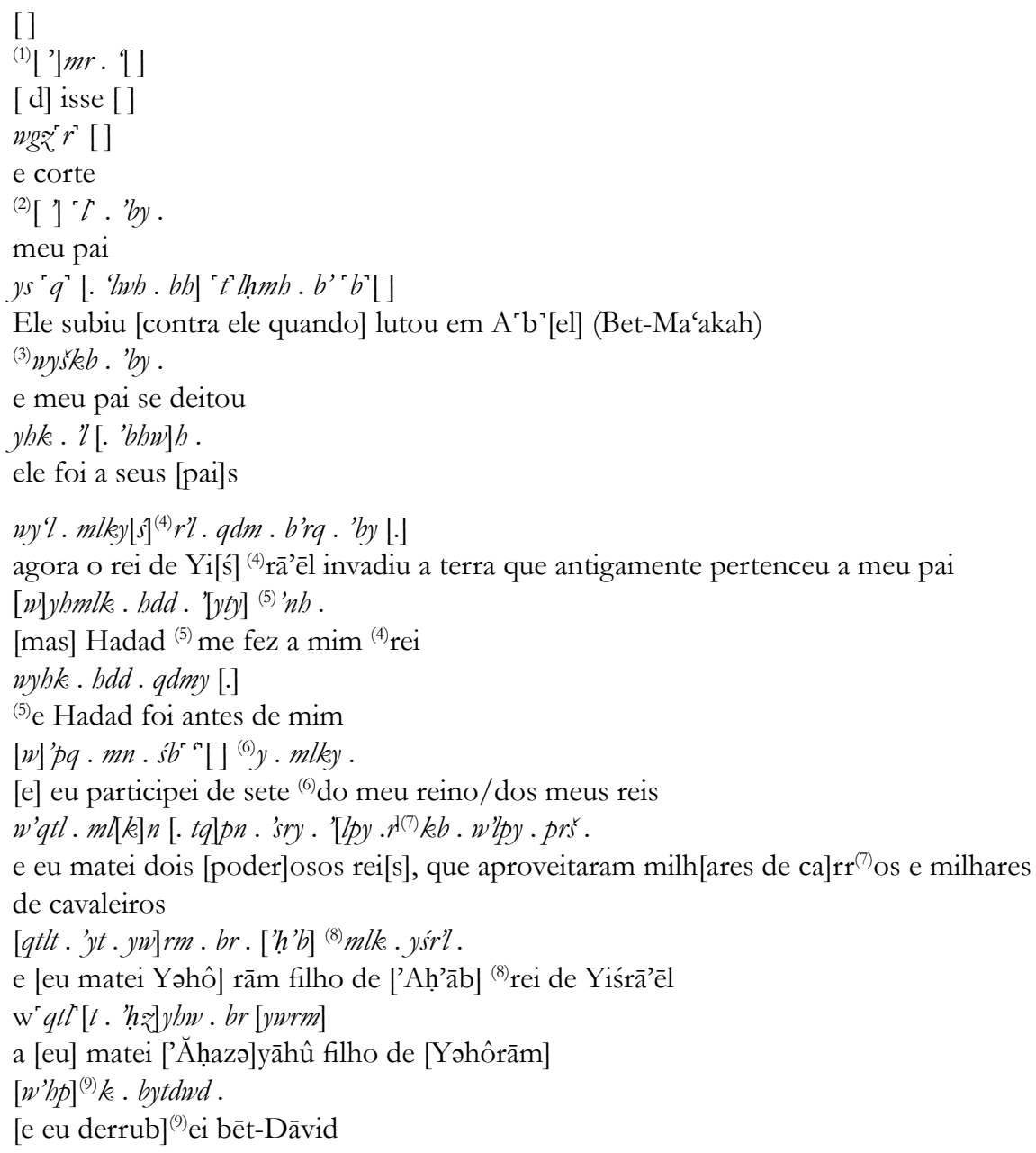




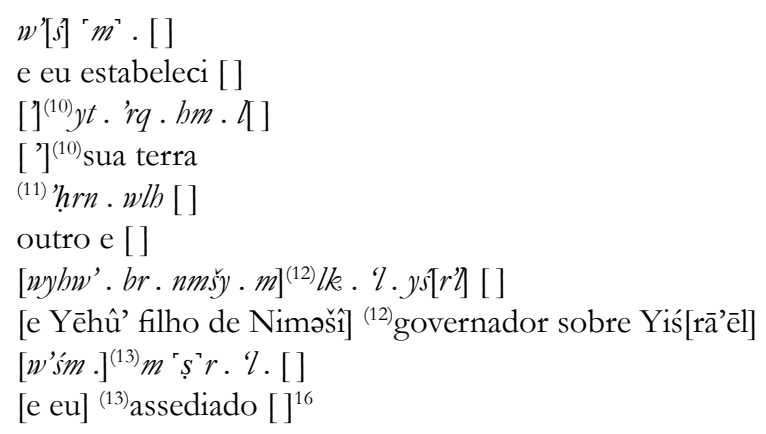

Figura 5. Documento monumental de Tēl Dān

(Fonte: www.antiquities.org.il/Israel Antiquities Authority)

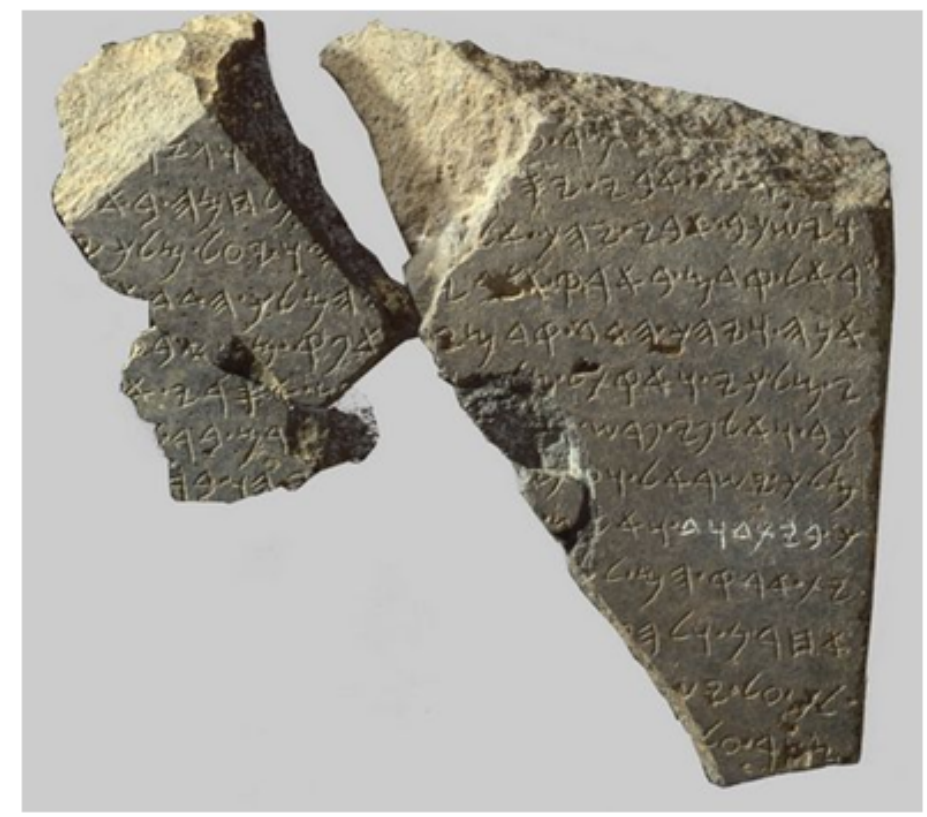

Como muitas fontes nas quais há narrativas de conquista e submissão, o documento fragmentário de Tēl Dān (fig. 5) tem sido considerado uma peça propagandística: um rei publica sua vitória e afirma a sua supremacia sobre rivais e inimigos. Em relação a Hazael, ele ainda enumera suas edificações reais. ${ }^{17}$ Medindo na extremidade de altura 32 centímetros e de largura máxima entre 20 e 22 centímetros, o documento monumental tem recebido transliteração e translação diversas, por isso citaremos outra versão de trecho pertinente.

${ }^{16}$ Com algumas modificações técnicas, seguimos as transliterações e translação de Younger (2016, p. 593-97).

${ }^{17}$ Destacou-se recentemente a natureza propagandística ao analisar a escrita e a ideologia reais em documentos antigos (Santos, 2018). 
[ di]sse $\mathrm{x}$ [ ] e cor[tou ]

[ ] x meu pai sub[iu contra ele quando] ele lutou em x[ ]

Então meu pai se deitou e foi a seus

[pais]. Subiu o rei de I[s]rael antes do tempo na terra de meu pai, [mas]

Hadad [me] fe[z] rei [ ]

$x$ Hadad foi antes de mim [e] eu fui de $x$

[ ]

de meus rei[s] eu matei re[is] que aproveitaram $\mathrm{x}$

[ca]rros e milhares de cavaleiros

[ ] rm filho de [ ]

rei de Israel e mata[ram ]yahu filho de [eu derrub]ei a casa de Davi. Eu impus

[tributo ]

$\mathrm{x}$ sua terra a $[$ ]

outro e ao [foi/se tornou re]i sobre Is[rael ] contra assédio [ $]^{18}$

Translação do Fragmento B

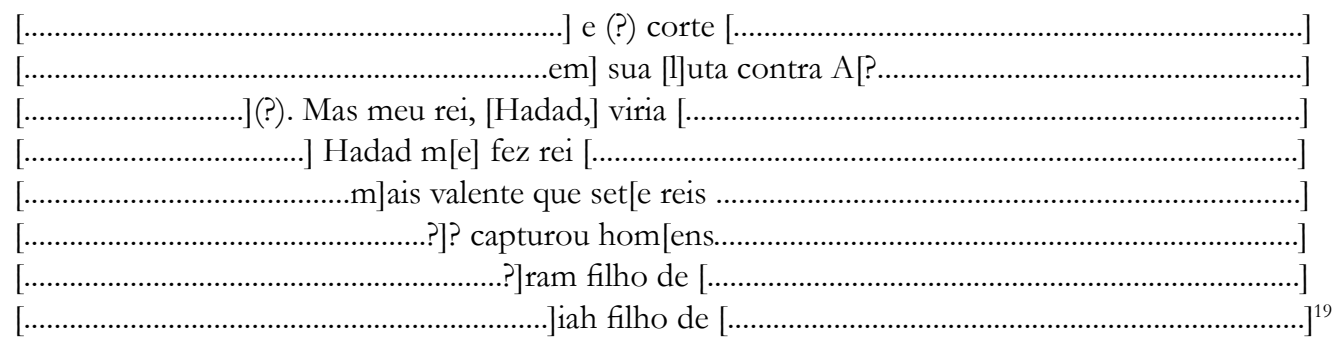

\section{Contextos dos CONFLitos: AS LINGUAGENS}

O uso da escrita alfabética nas cortes reais no sul do Levante no final do século X, para a documentação administrativa, tem semelhança com as descobertas em Gu-ub-la (heb.: Gəbal; gr.: Býblos); as inscrições formalmente dirigidas às divindades aparecem na região no final do século IX, no período de ausência da presença imperial assíria ( $\mathrm{Na}$ ’aman, 2000, p. 96). Com relação ao documento monumental, a inscrição não inicia informando sobre a guerra entre as duas mais importantes grandezas socioétnicas do sul do Levante, mas, pelo contrário, explanando sobre o antigo trato político envolvendo Aram e Israel Norte, nas linhas 1-2. Na interpretação da linguagem empregada na inscrição, Blum (2016, p. 41-42) entende que a guerra mencionada é entre Adad-'idrī (Hadad-'ezer) e Shalmaneser III, e que a questão da menção a Hazael nessa guerra diz respeito ao registro da morte do "pai" dele na batalha. Blum lê nas linhas 4-6 da inscrição "... meu pai ficou ferido quando lutou contra a Assíria", dizendo ser irrelevante o início da sentença com o substantivo 'by ysq $[b \ldots$ b'] thmmb b'šr ou com o verbo ysq[b 'by b']thmmb b'šr.

\footnotetext{
${ }^{18}$ Baseamo-nos para esta tradução da inscrição na versão de Alan R. Millard (2000, p. 161-62).

${ }^{19}$ A translação da inscrição foi por nós realizada considerando a obra de Athas (2006, p. 254-55).
} 
Com relação a 'ab, "pai", este é usado no muito recomendado sentido mais amplo de "patrono", ${ }^{20}$ o que concorda com a pecha assíria de que Hazael é mār lā ma-m-mā-na, "filho de um ninguém" em inscrição da "Estátua de Basalto de Aššūr", de cerca de 833, outro codinome para šar hamma't, "o usurpador". Na inscrição, "pai” segue a tradição real e não necessariamente indica uma referência biológica, mas um predecessor ou patrono, cujo objetivo é agregar para o novo rei honra ao mesmo tempo em que legitima a sua chegada ao poder - a quem pertencerá o local e a gente. Assim como a função literária da inscrição, o monumento é representativo do desenvolvimento linguístico da época, notadamente da assim chamada escrita cursiva, ${ }^{21}$ e do quadro político do Levante.

No aspecto religioso, o documento apresenta dupla função de categorias diferentes, mas não separadas, por reunir os sujeitos humano (o rei) e divino (Hadad/Hadadu). Aqui divergimos de Hadi Ghantous (2013, p. 63), quando ele afirma que são categorias separadas. Entendemos que nos domínios das políticas reais do antigo Oriente-Próximo a política, o sistema da cultura de escrita e a religião tantas vezes chegam à univocidade burocrática.

No entanto, o principal motivo da revolta violenta de Hazael contra Israel, a apropriação de território aramita por Omri, não é atestada por descoberta arqueológica. Eis a avaliação de Israel Finkelstein (2015, p. 132):

Uma revisão da situação geográfica antes de Hazael revela que a expansão de um rei israelita dentro dos territórios de Damasco não poderia ter ocorrido quando Israel e Damasco se uniram contra a Assíria, ou seja, anterior à batalha de Carcar, em 853 a.C. Por isso, o momento mais lógico seria nos dias pós-Ahab, possivelmente durante o reinado de Jorão, pouco antes da ascensão de Hazael ao poder. Os territórios aos quais Hazael se refere poderiam ter sido o vale do Jordão, ao norte do mar da Galileia, em torno de Hasor, e ainda mais para o norte se reconstroem as linhas abertas da inscrição de Dã (linha 2), que evidenciam que o rei de Israel lutou com o predecessor de Hazael em Abel-Bet-Maaca. Outra possibilidade que não pode ser descartada é a de que Hazael aponta para a expansão omrida dentro do que ele considerava territórios de Damasco, no nordeste de Galaad. Isso pode explicar a localização da batalha decisiva entre Aram e Israel em Ramot de Galaad, provavelmente nos dias de Jorão (842 a.C.).

Assim, localizamos o problema político em torno das fronteiras territoriais (fig. 6), nos altiplanos. Aí localizam-se as fortalezas de Har Adir e Tel Harasim, com características arquitetônicas omridas, demonstração do antigo domínio israelita. Finkelstein (2015, p. 134) afirma que a questão da fronteira deve ser resolvida com a identificação do construtor da fortaleza de casamata de En Gev (Hirbat al-'Asiq), numa comparação com Betsaida,

\footnotetext{
${ }^{20}$ Assim também Kottsieper (2007, p. 119), para quem o significado figurativo do termo "pai”" usado por Hazael é "óbvio".

${ }^{21}$ Sobre isto, indicamos a importante pesquisa de Benjamin Sass (2016).
} 
E ISRAELITAS NA IDADE DO FERRO II

localizada no extremo norte da Galileia. "As fortificações de Betsaida são semelhantes às de Tel Dã", ambas cercadas por muro e com elementos aramitas - o que pressupõe o domínio de Damasco. Por outro lado, na fronteira, En Gev tem arquitetura semelhante a Ḥașōr (estrato X) e Har Adir - o que leva-nos a afiliarmos a região a Israel.

Figura 6. Mapa das guerras entre aramitas e israelitas do norte no século IX AEC

(Fonte: https://www.preceptaustin.org/bible_maps)

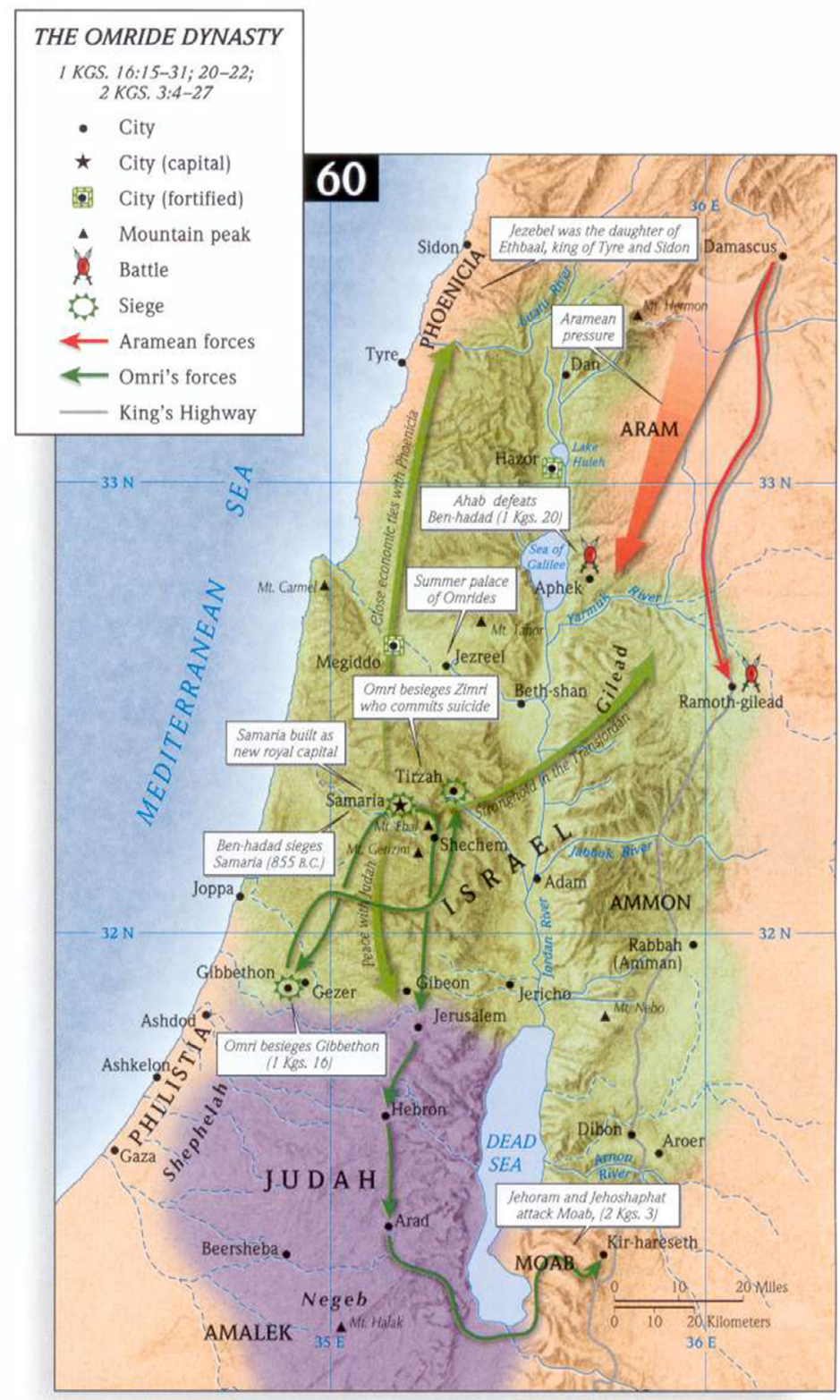


Por esse plano de fundo, aparece Jehu, o usurpador do trono israelita, num cenário de legitimação do reinado de Hazael, usurpador do trono aramita ao assassinar o rei Adad-

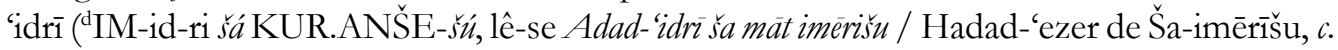
880-843). Stefania Mazzoni (2014, p. 689; cf Younger, 2016, p. 597, 602-603), após a análise de várias fontes, conclui que Hazael, um dos oficiais, assassina o rei Adad-'idrī. A prática não se limita ao contexto das ações estritamente políticas das camadas dirigentes, um rei podia ter como usurpado até mesmo o próprio nome. Norman Yoffee (2013, p. 116) cita o caso do rei Sargon de Acádia (c. 2350): Sargon, "Verdadeiro Rei", era "nome que foi usurpado, provinha da região em torno de Kish", capital dos acádios.

Contra Na'aman, a postulação da autoria de Hazael tem a seu favor os indícios narrativos, além de possibilitar a pesquisa comparativa com a historiografia denteronomística vinculada aos movimentos vitais do antigo Oriente-Próximo, inscritos e encenados nas fontes assírias. O historiógrafo israelita indica a adesão profética à ascensão de Hazael ao trono de Aram desde o reinado de Omri. Posteriormente, a intensidade dos conflitos resultou em uma sequência de desastres para o reino israelita. Por outras expressões: crise política generalizada, membros da aristocracia palacial assassinados, perdas territoriais na Transjordânia, regionalmente o rompimento da coalizão antiassíria, cujo último registro é de 845, e a submissão ao império neoassírio. Sem dúvida, o grande êxito de Hazael foi unificar Aram e processar a paz agregando Damasco, 'Abel Bēt Mā'akāh, Bēt Rehob (Bēt Ruhūūbu) e, a oriente do lago da Galileia, encampar a terra de Gi-šur-ra-a (Gešur).

Historicamente, os conflitos políticos no sul do Levante - as regiões siropalestinense e transjordaniana - lançam luz para os pequenos reinos, povos antes periféricos, mesmo que ainda sob a influência política da Assíria e do Egito (Mi-iș-ri; KUR mu-uș-ra-a-a, terra dos egípcios). As regiões levantinas tornam-se palco das ações imperiais. "A guerra de Hazael contra Israel visava recuperar o território aramita tomado por Omri, a recusa de Joram (ou Jehu) em apoiar Hazael quando as tropas de Shalmaneser III se aproximavam poderia ter desempenhado um papel semelhante à guerra bíblica sírio-efraimita" (Ghantous, 2013, p. 64). Destarte, temos pesquisas de acordo com o fato de que a Bêt Dāwid certamente era a identificação geográfica no Levante para o Estado tribal de Judah. Assim o documento qualifica e quantifica o debate em torno da historicidade do Dāwid israelita - a nosso ver, a Bêt Dāwid representa o sistema tributário oriundo do cacicado.

$\mathrm{O}$ documento monumental aramita apresenta obscuridades quanto à forma da sociedade, ou seja, sem clareza a uma presumível violação do trato político envolvendo o pai do narrador.

[ ] x meu pai sub[iu contra ele quando] ele lutou em x[ ]

Então meu pai se deitou e foi a seus

[pais]. Subiu o rei de I[s]rael antes do tempo na terra de meu pai

Mas não apenas por isso, o documento tem sido objeto de debates sobre a emergência palacial de Hazael ([mas] // Hadad [me] fe[z] rei [ ]) e mesmo sobre o encaixe dos fragmentos 
A e B como parte do mesmo artefato. ${ }^{22}$ Outro aspecto do debate é a irresolvida significância do lexema na linha 9 do Fragmento A, bytdwd (פל ביתדוד). Há quem construa uma completude frasal com $[m \rrbracket k$ byt dwd ou [wyb]k byt dwd, ou, por outro lado, [ns]k byt dwd. Galil (2001; cf. Schniedewind, 1996, p. 80-1) prefira a primeira possibilidade e refute a ideia de uma divindade aramita chamada $d w d$ ("Dod" ou Daud?) ou o templo dessa divindade. No entanto, esta palavra sequer caracteriza-se como um topônimo no antigo Oriente-Próximo.

Consideramos acertada tal argumentação, mas diante do debate que se estabeleceu por meio dos postulados oferecidos por Kottsieper, faz-se necessário confirmar aqui que Athas (2006, p. 248-53) tem em riste literalmente Galil e as interpretações iniciais de Biran e Naveh quando contrapõe: ביתדוד não é um "rótulo dinástico para Judah, mas sim um topônimo identificando Jerusalém como uma cidade-estado. É um paralelo aramita ao hebraico עיר דוד ('Cidade de Dawid')", o que não deixa de ser uma "entidade política" (מכלי[ל] ביתדוד não é um rótulo dinástico do pequeno reino de Judah à semelhança de Bīt-Hazā-il (Aram-Damasco), Bīt-Agūsi (Arpad), Bìt- ${ }^{\mathrm{m}} h u$-um-ri-i (Israel), Bīt Rehov e Bīt-Adīni (Til Barsip/Tell Aḥmar). Apesar da complexidade do monumento documental, há quem se comprometa com uma datação para a inscrição: Na'aman (2000, p. 100) assume o final dos anos 830, com o abandono da região por Shalmaneser III em 838.

Em adição, cumpre acentuar que nas inscrições assírias a soletração de sir-'a-la-a-a é resultado da metátese ou transposição de fonemas das primeiras duas letras do nome de Israel/Yiśrā'ēl, ysrl $\rightarrow$ syrl. Assim, elucidamos evidências de que a assim chamada estela de Tēl Dān, apesar de não fornecer detalhes da organização política do novo rei aramita, permite-nos aproximar filológica e historicamente do projeto expansionista e dos ataques ao território israelita, como comprovação material do avanço de Hazael.

\section{REFERÊNCIAS}

ATHAS, G. The Tel Dan inscription: a reappraisal and a new interpretation. London: Sheffield, 2003.

ATHAS, G. Setting the record straight: what are we making of the Tel Dan inscription?. Journal of Semitic Studies, Oxford, v. 51, n. 2, p. 241-255, 2006.

BIRAN, A.; NAVEH, J. The Tel Dan inscription: a new fragment. Israel Exploration Journal, Jerusalem, v. 43, n. 2-3, p. 81-98, 1993.

BIRAN, A.; NAVEH, J. The Tel Dan inscription: a new fragment. Israel Exploration Journal, Jerusalem, v. 45, n. 1, p. 1-18, 1995.

BLUM, E. The relations between Aram and Israel in the $9^{\text {th }}$ and $8^{\text {th }}$ centuries BCE. In: OMER, S.; OEMING, M.; HULSTER, I. J. de (Ed.). In search for Aram and Israel: politics, culture, and identity. Tübingen: Mohr Siebeck, 2016, p. 37-56. (Orientalische Religionen in der Antike, 20).

\footnotetext{
${ }^{22}$ Sobre isso, Hafpórsson (2006a, p. 50-55) enuncia o debate em torno da reconstrução operada por Biran e Naveh.
} 
BOTTÉRO, J. La religión más antigua: Mesopotamia. Traducción de M. Tabuyo y A. López. Madrid: Editorial Trotta, 2001.

BRAUDEL, F. O Mediterrâneo e o mundo mediterrâneo na época de Filipe II. Trad. de G. C. C. de Souza. São Paulo: USP, 2016a. v. 1.

BRAUDEL, F. O Mediterrâneo e o mundo mediterrâneo na época de Filipe II. Trad. de G. C. C. de Souza. São Paulo: Editora da USP, 2016b. v. 2.

BUNNENS, G. Confrontation, emulation and ethno-genesis of the aramaeans in Iron Age Syria. In: OMER, S.; OEMING, M.; HULSTER, I. J. de (Ed.). In search for Aram and Israel: politics, culture, and identity. Tübingen: Mohr Siebeck, 2016, p. 253-280. (Orientalische Religionen in der Antike, 20).

DONNER, H. História de Israel e dos povos vizinhos. Trad. de C. Molz e H. Trein. São Leopoldo: Sinodal; Petrópolis: Vozes, 1997. v. 2.

ELLIGER, K.; RUDOLPH, W. (Ed.). Biblia Hebraica Stuttgartensia. 5. ed. Stuttgart: Deutsche Bibelgesellschaft, 1997.

FINKELSTEIN, I. The two kingdoms: Israel and Judah. In: SCHMIDT, B. B. (Ed.). The quest for the historical Israel: debating archaeology and the history of early Israel. Leiden: Brill, 2007, p. 147-157.

FINKELSTEIN, I. O reino esquecido: arqueologia e história de Israel Norte. Trad. de S. K. Cardoso e É. V. S. de Mendonça. São Paulo: Paulus, 2015.

GALIL, G. A re-arrangement of the fragments of the Tel Dan inscription and the relations between Israel and Aram. Palestine Exploration Quarterly, London, v. 133, p. 16-21, 2001.

GHANTOUS, H. The Elisha-Hazael paradigm and the kingdom of Israel: the politics of God in ancient Syria-Palestine. London: Acumen Publishing, 2013.

HAFDÓRSSON, S. Aramaic texts. In: - Apassing power: an examination of the sources for the history of Aram-Damascus in the second half of the ninth century B.C. Stockholm: Almqvist \& Wiksell International, 2006a, cap. 3, p. 31-71.

HAFDÓRSSON, S. Archaeological Sources. Excavations in northern Palestine - Tall alQāọ̄i (Tel Dan). In: - A passing power. an examination of the sources for the history of Aram-Damascus in the second half of the ninth century B.C. Stockholm: Almqvist \& Wiksell International, 2006b, cap. 6, p. 222-229.

HASEGAWA, S. Aram and Israel during the jehuite dynasty. Berlin: Walter de Gruyter, 2012. (Beihefte zur Zeitschrift für die alttestamentliche Wissenschaft, 434).

HOBSBAWM, E. J. Introdução: a invenção das tradições. In: ; RANGER, T. (Org.). A invenção das tradições. 12. ed. Trad. de C. C. Cavalcante. Rio de Janeiro/São Paulo: Paz e Terra, 2018, p. 7-24. 
KILLEBREW, A. E. Israel during the Iron Age II period. In: STEINER, M. L.; KILLEBREW, A. E. (Ed.). The Oxford Handbook of the archaeology of the Levant. c. 8000-332 BCE. Oxford: Oxford University Press, 2014, p. 730-742.

KNITTER, D. et al. The centrality of Aleppo and its environs. eTopoi-Journal for Ancient Studies, Berlin, v. 3, p. 107-127, 2014.

KOTTSIEPER, I. The Tel Dan inscription (KAI 310) and the political relations between Aram-Damascus and Israel in the first half of the first millennium BCE. In: GRABBE, L. L. (Ed.). Ahab agonists: the rise and fall of the Omri dynasty. London: Bloomsbury, 2007, p. 104-134.

LIVERANI, M. Para além da Bíblia: história antiga de Israel. Trad. de O. S. Moreira. São Paulo: Loyola, 2008.

LIVERANI, M. The Book of Kings and ancient Near Eastern historiography. In: LEMAIRE, A.; HALPERN, B. (Ed.). The Books of Kings: sources, composition, historiography, and reception. Atlanta, GA: SBL Press, 2010, p. 163-184.

MAZZONI, S. The aramean states during the Iron Age II-III periods. In: STEINER, M. L.; KILLEBREW, A. E. (Ed.). The Oxford Handbook of the archaeology of the Levant. c. 8000-332 BCE. Oxford: Oxford University Press, 2014, p. 683-705.

MICHEL, C. Au-delà des frontières: le commerce des assyriens en Asie Mineure au début du II $^{\circ}$ millénaire av. J.-C. In: CERQUEIRA, F. V. et al. (Org.). Guerra e paz. no mundo antigo. Pelotas: Instituto de Memória e Patrimônio; Laboratório de Ensino e Pesquisa em Antropologia e Arqueologia da UFPel, 2007, p. 69-86.

MILLARD, A. R. The Tell Dan stele. In: HALLO, W. W. (Ed.). The Context of Scripture. Leiden: Brill, 2000. v. 2, p. 161-162.

MURPHY, S. B. Frontier as an interpretative key of relationship between nomads and sedentaries in ancient Mesopotamia. In: NICOLE, C. (Ed.). Amurru 3: nomades et sédentaires dans le Proche-Orient ancient. Compte rendu de la XLVI ${ }^{e}$ Rencontre Assyriologique Internationale (Paris, 10-13 juillet 2000). Paris: Éditions Recherche sur les Civilisations, 2004, p. $75-80$.

NA'AMAN, N. Three notes on the aramaic inscription from Tel Dan. Israel Exploration Journal, Jerusalem, v. 50, n. 1/2, p. 92-104, 2000.

POZZER, K. M. P. O banquete do rei e a política nos tempos de paz. In: CERQUEIRA, F. V. et al. (Org.). Guerra e paz no mundo antigo. Pelotas: Instituto de Memória e Patrimônio; Laboratório de Ensino e Pesquisa em Antropologia e Arqueologia da UFPel, 2007, p. 139-152.

SADER, $H$. The aramaeans of Syria: some considerations on their origin and material culture. In: LEMAIRE, A.; HALPERN, B. (Ed.). The Books of Kings: sources, composition, historiography, and reception. Atlanta, GA: SBL Press, 2010, p. 273-300. 
SANTOS, J. B. R. Pertinências entre os anais egípcios e a biografia antiga: ensaio historiográfico sobre escrita e ideologia nas inscrições cuneiformes e hieroglíficas de eventos oficiais e memoriais do Egito antigo. In: . Primeiro Testamento: estudos teóricos e exegéticos. São Bernardo do Campo: Editeo/Umesp, 2018, p. 73-94.

SASS, B. Aram and Israel during the $10^{\text {th }}-9^{\text {th }}$ centuries BCE, or Iron Age IIA: the alphabet. In: OMER, S.; OEMING, M.; HULSTER, I. J. de (Ed.). In search for Aram and Israel: politics, culture, and identity. Tübingen: Mohr Siebeck, 2016, p. 199-227. (Orientalische Religionen in der Antike, 20).

SCHNIEDEWIND, W. M. Tel Dan stela: new light on Aramaic and Jehu's revolt. Bulletin of the American Schools of Oriental Research, Chicago, n. 302, p. 75-90, 1996.

SERGI, O.; HULSTER, I. J. de. Some historical and methodological considerations: regarding the question of political, social and cultural interaction between Aram and Israel in the Early Iron Age. In: OMER, S.; OEMING, M.; HULSTER, I. J. de (Ed.). In search for Aram and Israel: politics, culture, and identity. Tübingen: Mohr Siebeck, 2016, p. 1-14. (Orientalische Religionen in der Antike, 20).

YAMADA, S. Aram-Israel relations as reflected in the aramaic inscription from Tel Dan. Ugarit-Forschungen, Münster, v. 27, p. 611-625, 1995.

YOFFEE, N. Mitos do Estado arcaico: evolução dos primeiros Estados, cidades e civilizações. Trad. de C. E. M. de Moura. São Paulo: USP, 2013.

YOUNGER Jr., K. L. A political history of the arameans: from their origins to the end of their polities. Atlanta, GA: SBL Press, 2016. 